\title{
The effect of the Wingate Anaerobic Test on NTproBNP, lactate and blood pressure in wrestlers and untrained young healthy males
}

\author{
Saghiv $\mathbf{M}^{* 1}$, Cummings $\mathrm{K}^{1}$, Kusser $\mathrm{K}^{1}$, Kvislen $\mathrm{K}^{1}$, Roemmich $\mathrm{L}^{1}$, Dinkel J' ${ }^{1}$ and Knoll $\mathrm{C}^{1}$ \\ ${ }^{1}$ The Department of Exercise Physiology, School of Health Sciences, University of Mary, Bismarck, ND, USA
}

\begin{abstract}
Purpose: To investigate the influence of the WAnT on blood pressure, lactate, and NTproBNP in trained Wrestlers and untrained young males.

Methods: 20 males ( $\mathrm{n}=20)$, ages 18-25 underwent the WAnT. The study included 2 groups. Group 1 included 10 untrained individuals, and group 2 included 10 wrestlers. NTproBNP ( $\mathrm{ng} / \mathrm{mL})$, lactate $(\mathrm{mmol} / \mathrm{L})$, and blood pressure $(\mathrm{mmHg})$ were measured at rest, immediate-post, two minutes post, and ten minutes post. The mechanical outputs $(\mathrm{W})$ calculated for each subject. NTproBNP was analyzed utilizing ELIZA.

Results: The wrestler's resting NTproBNP levels were higher $(35.5 \pm 7.59$ vs. $35.15 \pm 4.82$ accordingly), with non-significant differences between the groups. Immediate Post NTproBNP was higher for wrestlers $(40.25 \pm 14.08$ vs. $37.33 \pm 9.94)$ with a positive and strong correlation between PP and IP NTproBNP ( $\mathrm{r}=$ 0.85). While the untrained had a substantially higher post $10 \mathrm{NT}$ proBNP $(45.07 \pm 11.75$ vs. $32 \pm 5.57)$, both group's NTproBNP was elevated post 10 minutes with a significant difference from post 2 minutes values $(\mathrm{p}=0.035)$. PP was significantly higher for the wrestlers $(1031.6 \pm 188.65$ vs. $960.91 \pm 189.01)$. No significant differences were found between groups for RPP and RMP.

Conclusions: NTproBNP values were within the ranges reported in the literature. The WAnT did not put any of the subjects at risk due to cardiac stress. The recovery dynamics regarding NT proBNP were different between groups. Wrestlers recovered rapidly with a slight elevation 10 minutes post-test, while the untrained recovered slowly with a significant elevation of NTproBNP 10 minutes post-test.
\end{abstract}

\section{Introduction}

Often, field and lab test are utilized to predict sub-maximal and maximal performance. Such protocols exist in regards to both aerobic and anaerobic capacities. The Wingate Anaerobic Test (WAnT) is an all-out anaerobic performance exercise test, consistent of 30 seconds of maximal cycling on a cycle ergometer against $8 \%$ of the subject's body weight $(\mathrm{kg})$, while fully seated on the cycle. In sport science, the WAnT is a widely-administered protocol which despite its short duration evokes substantial cardiac work by requiring peak power outputs (Watts) up to $300 \%$ maximal workload (Wmax) [1]. Left ventricular function and physiological stress during the WAnT have been studied for several years via the effects of the test on $\mathrm{CO}(\mathrm{L} / \mathrm{min}), \mathrm{SV}(\mathrm{mL})$, and HR (bpm), as well as being compared to a GXT [1-5]. Brain Natriuretic Peptide (BNP, ng/mL), first isolated from porcine brain [6], is a second member of the natriuretic peptide family which is known to control cardiovascular and body fluid homeostasis. BNP $(\mathrm{ng} / \mathrm{mL})$ is released predominantly from the ventricular myocardium as a response to cardiac ventricular dilatation and pressure overload [7-8]. Increased circulating levels of BNP $(\mathrm{ng} / \mathrm{mL})$ and N-terminal pro-BNP (NTproBNP, ng/ $\mathrm{mL}$ ), a cleaved fragment of BNP precursor (amino acids 1-76), have been shown to be of prognostic value in patients with heart failure or coronary artery disease [9-12]. Although predominantly produced by the heart, NTproBNP $(\mathrm{ng} / \mathrm{mL})$ has also been found in neurons of discrete brain regions where its expression was shown to be 13 times higher than that of Atrial Natriuretic Peptide (ANP) [13]. In animal models, endogenous ANP $(\mathrm{ng} / \mathrm{mL})$ release from the hypothalamus during stress acts to suppress adrenocorticotropic hormone (ACTH) secretion [14-15]. This suggests that central NTproBNP (ng/mL) may also take part in the neuro-modulatory system that controls emotional behavior and the stress hormone cascade [16]. While there are data in the medical literature on NTproBNP $(\mathrm{ng} / \mathrm{mL}$ ) responses to acute physical stress [17-23], few data are available on systemic NTproBNP (ng/mL) responses to acute psychological and physiological stress. Moreover, it has been proposed that the cardiac endocrine response may be regulated differently by several types of stressors [24-25]. While NTproBNP (ng/mL) is commonly associated with cardiac patients and researched predominantly during aerobic exercise and since natriuretic peptides have powerful physiological effects on hemodynamic, body fluid, and electrolyte homeostasis and given the inhibitory action they share on neuro-hormonal and immunological systems [9-12], it is of interest to investigate the response of NTproBNP $(\mathrm{ng} / \mathrm{mL})$ to an acute all-out anaerobic performance test such as the WAnT and to correlate the peptide's levels to the mechanical outcomes (Watts) of the test, Lactate $(\mathrm{mmol} / \mathrm{L})$ and $\mathrm{BP}(\mathrm{mmHg})$.

Correspondence to: Moran S. Saghiv, Associate Professor, Exercise Physiology Department, Casey Center, Room 141B, University of Mary, 7500 University Drive, Bismarck, ND 58504, USA.

Key words: Wingate Anaerobic Test, anaerobic performance, cycle test, wrestlers, untrained, N' Terminal Natriuretic pro Brain Peptide, blood pressure, lactate

Received: March 18, 2017; Accepted: April 03, 2017; Published: April 07, 2017 


\section{Methods and measurements}

$20\left(\mathrm{n}_{\text {total }}=20\right)$ young, low risk, males, aged 18-25 years, all students at the University of Mary (Umary), Bismarck, ND, USA, have volunteered to participate in this study, receiving nothing in return. The subjects were assigned to one of two groups. The first group included 10 Umary wrestlers $(n=10)$, while the second group included 10 untrained students $(n=10)$. The first group's participants were recruited with the help of the wrestling coach and assistant coach; the second group's participants were recruited via word of mouth, posters and personal acquaintance of the researchers with the candidate subjects. The study received the Institute Review Board's (IRB) approval prior to subject enrollment and data collection.

Prior to enrollment, candidate subjects were sent an informed consent form, explaining the scope, background, purpose, methods, benefits and risks of the study, while encouraging the participants to meet with the team of researcher if they had any questions or concerns prior to signing the informed consent form. All subjects were instructed to sleep at least 7 hour, avoid caffeinated beverages and avoid exercising prior to data collection visits. All subjects were given a sheet with the instructions prior to data collection and were reminded by a team member the day before data collection by email or phone. Subjects self-reported in regards to their sleep hours, caffeine consumption and extent of exercising prior to testing.

To ensure the protection of the subjects' private information and result according to HIPAA regulations, each subject enrolled into the study, was given a unique ID, information was kept behind lock and key at the Department of Exercise Physiology offices, under the supervision of the leading researcher.

Upon the first visit to the lab, the informed consent form was either submitted signed or was signed on the spot, afterwards signed by one of the researchers as a witness. An Umary heath history questionnaire, established according to the guidelines of the American College of Sports Medicine (ACSM) was then filled-out by the candidate subject; questions regarding the questionnaire were answered on site by the researchers. The information obtained from the health history questionnaire was used to conduct risk stratification according to the ACSM guidelines. Only subjects that have been found to be of low risk were included in the study.

Upon inclusion in the study, the subject's weight $(\mathrm{kg})$, height $(\mathrm{cm})$, resting heart rate $(\mathrm{HR}, \mathrm{bpm})$, blood pressure $(\mathrm{BP}, \mathrm{mmHg})$, lactate $(\mathrm{mmol} / \mathrm{L})$ and NTproBNP $(\mathrm{ng} / \mathrm{mL})$ were measured. After sitting for 5 minutes while doing nothing, $5 \mathrm{~mL}$ of blood were extracted by either a nurse or certified phlebotomist from the cuboidal vein, and were immediately injected into a pre-labeled EDTA tube. Blood Samples were centrifuged, the serum extracted and refrigerated until analyzed via ELISA for NTproBNP concentration $(\mathrm{ng} / \mathrm{mL})$. Weight $(\mathrm{kg})$ and height $(\mathrm{cm})$ were measured via a standard calibrated scale; HR (bpm) was measured via a Polar heart rate monitor and strap; Systolic and Diastolic blood pressure (SBP; DBP, $\mathrm{mmHg}$ ) were measured via an Omron sphygmomanometer; Lactate $(\mathrm{mmol} / \mathrm{L})$ was measured via a fingertip Point of Care (POC) lactate meter, and the Monark E804 Cycle Ergometer seat height (notches) was fitted and recorded.

The subjects then were explained once more the protocol of the test, given instructions regarding points of contact with the cycle, breathing, cycling, and were tested via a familiarization test at 50\% (4\% of the subject's body weight) of the full test's intensity. The purpose of the familiarization test was to customize the subject to the length of the test, protocol and procedures. Immediate-post; post 2 minutes and post 10 minutes were not measured during the familiarization test. The mechanical outcomes (PP, MP, AC, RPP, RMP and FI) were immediately calculated and results were explained to the subject to customize him with the over-all way of analyzing the results and the mechanical outcomes. The mechanical outcomes of the familiarization test were not recorder, and were used for practice only.

The subject then stayed at the lab with supervision, until his vitals (HR and BP) were within baseline/resting values and was released if no signs of physical or psychological distress were apparent. Subjects that were dizzy, nauseas, light-headed or have fainted were treated on spot by the researcher until they were back to normal with positive and normal vitals.

4-7 days after the first visit, the subjects reported to the lab for the second and last time, in which they underwent the full Wingate Anaerobic Test against $8 \%$ of their body weight $(\mathrm{kg})$. Resting vitals (HR and BP) were measured to assure that nothing has changed from the subject's last visit with the team, and the subject was questioned to assure that no changes, events or any other stressor/influencers have occurred that may influence the results of the visit. NTproBNP (ng/ $\mathrm{mL})$; lactate $(\mathrm{mmol} / \mathrm{L})$; and $\mathrm{BP}(\mathrm{mmHg})$ were measured immediately post-test, 2 minutes post-test, and 10 minutes post-test. Immediate post-test measurements were obtained while the subject was still seated on the cycle; 2 minutes post-test, and 10 minutes post-test measurement were obtained while the subject was supine on a plinth.

Both in the familiarization and full test, a warm-up was conducted, which included 3 consecutive cycles of $55 \mathrm{sec}$ of cycling at a low pace $(\approx 40 \mathrm{rpm})$ followed by $5 \mathrm{sec}$ bouts of all-out cycling. Afterwards the subject sat on the cycle for 1:57 minutes and seconds, until instructed to achieve maximal cadence within 3-5sec. As the researchers estimated that maximal cadence has been achieved, the resistance $(4 \%$ or $8 \%$ of body weight, $\mathrm{kg}$ ) was applied to the cycle (the weights that sat in a basket, were released by a push of a button), and the 30 sec test began. All subjects were encouraged verbally.

\section{Blood sample analysis (ELISA)}

Blood samples were immediately transferred to the Department of Biology at the University of Mary (a 3 minute walk from the Physiology lab). Samples were centrifuged at $1200 \mathrm{rpm}, 23^{\circ} \mathrm{C}$ for 10 minutes to separate the serum.

Serum was then pipetted out of the EDTA tubes; the rest of the EDTA tube's content was thrown away and destroyed. The serum extract was kept in micro-tubes and refrigerated until analysis via ELISA.

NTproBNP concentrations $(\mathrm{pg} / \mathrm{mL})$ were obtained via a RayBIO ${ }^{\circ}$ Human proBNP ELISA Kit (catalog\#: ELH-proBNP) while following accurately the instructions of RayBIO ${ }^{\circ}$. The minimum detectable dose of human proBNP of the kit was determined by RayBIO ${ }^{\circ}$ to be 0.14 $\mathrm{ng} / \mathrm{mL}$ (2 standard deviations above that of the diluent buffer/blank). Regarding reproducibility, the intra-assay $\mathrm{CV} \%$ was $<10 \%$, and the inter-assay $\mathrm{CV} \%$ was $<12 \%$.

The assay employs an anti-body specific for human proBNP coated on a 96 -well plate. 8 standards $(100 \mathrm{ng} / \mathrm{mL} ; 33.33 \mathrm{ng} / \mathrm{mL} ; 11.11 \mathrm{ng} / \mathrm{mL}$; $3.7 \mathrm{ng} / \mathrm{mL} ; 1.235 \mathrm{ng} / \mathrm{mL} ; 0.412 \mathrm{ng} / \mathrm{mL} ; 100 \mathrm{ng} / \mathrm{mL} ; 0.137$ and $0 \mathrm{ng} / \mathrm{mL}$ (zero)) and samples were pipetted into the wells, and proBNP present in the well was bound to the well via the immobilized anti-body. The wells were then washed and biotinylated anti-human proBNP anti- 
body was added. After washing away, unbound biotinylated anti-body, HRP-conjugated streptavidin was pipetted into the wells, afterwards, the wells were once more washed, and a TMB substrate solution was added. A blue color was developed in proportion to the amount of proBNP bound to the well. The addition of a stop solution changed the color from blue to yellow; the intensity of the yellow color was measured at $450 \mathrm{~nm}$ by the ELISA reader.

Serum was loaded into 3 wells for every sample taken (baseline; immediate post; 2 minutes post and 10 minutes post). The average of the results of the 3 wells was calculated and is presented as the representing value of NTproBNP for that sample. A well result that was significantly higher than $(\geq 0.5 \mathrm{ng} / \mathrm{mL})$ than the 2 other wells for the same sample, was excluded from the calculation, and the average of the other 2 wells was used.

\section{Data analysis}

SPSS 23.00 for Windows was utilized to analyze the data of the study. A two-way ANOVA with repeated measures was used to calculate averages, standard deviations and correlations between variables. Variables are presented as mean $\pm \mathrm{SD}$, and significance $(\mathrm{p} \leq 0.05)$.

\section{Calculations and definitions}

1. WAnT resistance $(\mathrm{kg})=0.08 \times$ subject's body weight $(\mathrm{kg})$

2. Peak power $\left(\mathrm{PP}\right.$, Watts $\left.5 \mathrm{sec}^{-1}\right)=$ distance $(\mathrm{rpm} \times 6 \mathrm{~m}) \times$ resistance $(\mathrm{kg}) \times$ time $^{-1}(5 \mathrm{sec})$. The highest amount of work produced within the first 5 seconds of the test.

3. Lowest power $\left(\mathrm{LP}\right.$, Watts $\left.\cdot 5 \mathrm{sec}^{-1}\right)=$ distance $(\mathrm{rpm} \times 6 \mathrm{~m}) \times$ resistance $(\mathrm{kg}) \times$ time $^{-1}(5 \mathrm{sec})$. The lowest amount of work produced within the last 5 seconds of the test.

4. Mean power (MP, Watts.1 $\left.1 \mathrm{sec}^{-1}\right)=\mathrm{AC} \times 30^{-1}$. The average amount of work produced per second of the test.

5. Anaerobic capacity (AC, Watts.30sec $\left.{ }^{-1}\right)=\bigotimes_{i-n} P_{i}$; whereas $P_{i}$ is the power produced at any point starting at the beginning of the test (i) to the end (n). The sum of work produced throughout the test.

6. Fatigue index $(\mathrm{FI}, \%)=\left[(\mathrm{PP}-\mathrm{LP}) \times \mathrm{PP}^{-1}\right] \times 100$. The loss of percentage of power from the start of the test, to its end.

7. Body weight relative peak power (RPP, Watts $\left.5 \mathrm{sec}^{-1} \cdot \mathrm{kg}^{-1}\right)=\mathrm{PP}$ $\times$ (body weight $)^{-1}$. The relative contribution of each $\mathrm{kg}$ of body weight to the peak power produced during the first 5 seconds of the test.

8. Body weight relative mean power $\left(\mathrm{RMP}\right.$, Watts $\left.\cdot 1 \mathrm{sec}^{-1} \cdot \mathrm{kg}^{-1}\right)=$ $\mathrm{MP} \times(\text { body weight })^{-1}$. The relative contribution of each $\mathrm{kg}$ of body weight to the mean power produced during the test.

\section{Results}

All subjects completed the study without severe events, injuries or apparent psychological problems. Subjects' age (years), height $(\mathrm{cm})$, weight $(\mathrm{kg})$, BMI $\left(\mathrm{kg} / \mathrm{m}^{2}\right)$ and full WAnT test resistances $(\mathrm{kg})$ are presented in Table 1.

A positive and strong correlation was found between peak power and immediate-post NTproBNP levels for both wrestlers and untrained $(\mathrm{r}=0.85 ; \mathrm{r}=0.81$; accordingly). This was the only strong (above weak) correlation found between NTproBNP and other variables of the study.
Significant differences were found between untrained and wrestlers regarding the 10 minutes post-test NTproBNP $(\mathrm{ng} / \mathrm{mL})$ levels $(45.1$ \pm 11.75 vs. $32 \pm 5.6$, accordingly). The wrestlers' immediate posttest lactate $(\mathrm{mmol} / \mathrm{L})$ levels were significantly higher than those of the untrained $(12.5 \pm 2.5$ vs. $7.3 \pm 1.98$, accordingly). The wrestlers' 2 minutes post-test lactate $(\mathrm{mmol} / \mathrm{L})$ levels were significantly higher than those of the untrained $(12.4 \pm 3.2 v s .11 .6 \pm 2.48$, accordingly). In addition, the wrestlers' 10 minutes post-test lactate $(\mathrm{mmol} / \mathrm{L})$ levels were significantly lower than those of the untrained $(11.0 \pm 3.9 \mathrm{vs.} 12.2$ \pm 4.67 , accordingly).

While the wrestlers' immediate post systolic blood pressure (mmHg) was significantly higher than the untrained subjects', the wrestlers' 2 minute post-test systolic blood pressure $(\mathrm{mmHg})$ was significantly lower in comparison to that of the untrained (171.0 \pm 11.1 vs. $161.0 \pm 17.17$ and $143.3 \pm 24.1$ vs. $160.3 \pm 33.79$; accordingly). Wrestlers presented a significantly higher diastolic blood pressure $(\mathrm{mmHg})$ at baseline; immediate post; 2 minutes post-test and 10 minutes post-test, in comparison to the untrained subjects $(76.4 \pm 10.1$ vs. $70.2 \pm 12.49 ; 75.3 \pm 9.6$ vs. $69.7 \pm 12.08 ; 75.0 \pm 11.3$ vs. $66.2 \pm 11.78$; $73.2 \pm 7.8 v s .63 .5 \pm 11.25$; accordingly).

The comparison of the mechanical outcomes between groups clearly shows that the wrestlers' peak power (Watts. $5 \mathrm{sec}^{-1}$ ); mean power (Watts.sec ${ }^{-1}$ ) and anaerobic capacity (Watts.30 $\mathrm{sec}^{-1}$ ) were significantly higher than those of the untrained. The wrestlers' peak power (Watts. $5 \mathrm{sec}^{-1}$ ) was $1,291.6 \pm 702.66$ while the untrained subjects' was $1,070.5 \pm 523.97$; mean power (Watts. $\mathrm{sec}^{-1}$ ) was $736.4 \pm 85.84$ while the untrained subjects' was $678.25 \pm 85.92$; anaerobic capacity (Watts.30 sec $^{-1}$ ) was $22,103.5 \pm 2,581.04$ while the untrained subjects' was $20,358.5 \pm 2,625.89$. All other comparisons between groups were insignificant (Figure 1).

Differences between groups in regards to mechanical outcomes, NTproBNP $(\mathrm{ng} / \mathrm{mL})$, lactate $(\mathrm{mmol} / \mathrm{L})$ and blood pressure $(\mathrm{mmHg})$ at baseline, immediate post, 2 minutes post and 10 minutes post are presented in Table 2.

\section{Discussion}

While NTproBNP $(\mathrm{ng} / \mathrm{mL})$ responses to aerobic exercise in healthy and diseased are well documented, little to none is known about the effects of anaerobic exercise on this bio-marker [26].

In the present study, wrestlers and untrained young healthy males underwent a full Wingate Anaerobic Test (WAnT, $8 \%$ of body weight), following a "familiarization Wingate Anaerobic Test" at $4 \%$ of their body weight $(\mathrm{kg})$ as resistance. While the WAnT is widely used to evaluate anaerobic maximal performance ${ }^{1}$, to the best of the researchers' knowledge, the level of cardiac stress produced was never quantified via a bio-marker such as NTproBNP (ng/mL). Furthermore, the correlations between the mechanical outputs of the test were never before correlated to the concentration of NTproBNP (ng/mL).

Table 1. Age; height; weight; BMI and WAnT test resistance according to group (mean $\pm \mathrm{SD})$.

\begin{tabular}{|c|c|c|}
\hline Variable & Wrestlers & Untrained \\
\hline Sample size $(\mathrm{N})$ & 10 & 10 \\
\hline Age $($ years $)$ & $20.6 \pm 1.5$ & $20.3 \pm 1.00$ \\
\hline Height $(\mathrm{cm})$ & $177.4 \pm 7.5$ & $180.6 \pm 7.6$ \\
\hline Weight $(\mathrm{kg})$ & $84 \pm 13.8$ & $76.5 \pm 9.6 \dagger$ \\
\hline BMI $\left(\mathrm{kg} / \mathrm{m}^{2}\right)$ & $26.6 \pm 3.4$ & $23.6 \pm 3.4 \dagger$ \\
\hline WAnT test resistance $(\mathrm{kg})$ & $6.7 \pm 1.1$ & $6.2 \pm 0.7 \dagger$ \\
\hline
\end{tabular}

$\mathrm{BMI}=$ Body Mass Index; $\uparrow=$ significant differences between groups, $\mathrm{p} \leq 0.05$. 


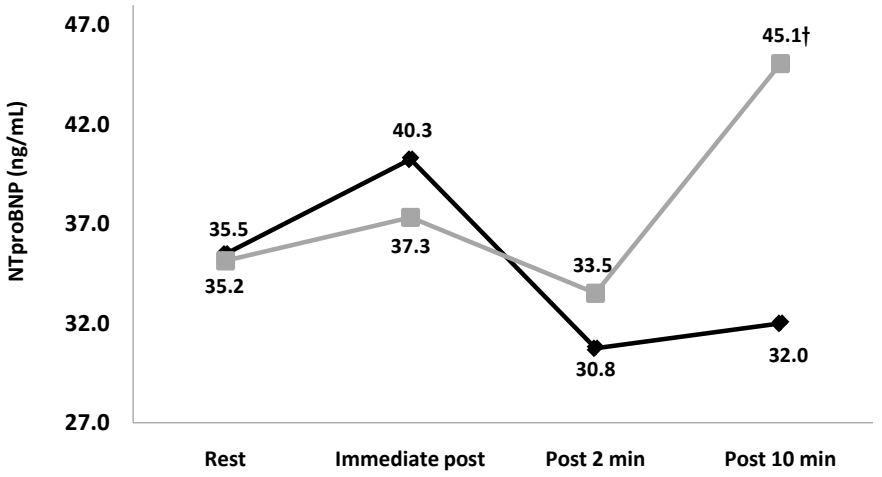

Figure 1. Changes in NTproBNP concentrations $(\mathrm{ng} / \mathrm{mL})$ according to time and group $($ mean $\pm \mathrm{SD})$.

Table 2. NTproBNP; Lactate, BP, and mechanical outcomes at rest; immediate-post; 2 minutes post; and 10 minutes post, according to group (mean $\pm \mathrm{SD}$ ).

\begin{tabular}{|c|c|c|}
\hline Variable & Wrestlers & Untrained \\
\hline Baseline NTproBNP (ng/mL) & $35.5 \pm 7.6$ & $35.2 \pm 4.83$ \\
\hline IP NTproBNP (ng/mL) & $40.3 \pm 14.1$ & $37.3 \pm 9.94$ \\
\hline $2 \mathrm{~min}$ post NTproBNP $(\mathrm{ng} / \mathrm{mL})$ & $30.8 \pm 6.0$ & $33.5 \pm 5.81$ \\
\hline 10min post NTproBNP $(\mathrm{ng} / \mathrm{mL})$ & $32.0 \pm 5.6$ & $45.1 \pm 11.75 \dagger$ \\
\hline Baseline lactate $(\mathrm{mmol} / \mathrm{L})$ & $1.9 \pm 1.2$ & $2.2 \pm 0.93$ \\
\hline IP lactate $(\mathrm{mmol} / \mathrm{L})$ & $12.5 \pm 2.5$ & $7.3 \pm 1.98 \dagger$ \\
\hline $2 \mathrm{~min}$ post lactate $(\mathrm{mmol} / \mathrm{L})$ & $12.4 \pm 3.2$ & $11.6 \pm 2.48 \dagger$ \\
\hline $10 \mathrm{~min}$ post lactate $(\mathrm{mmol} / \mathrm{L})$ & $11.0 \pm 3.9$ & $12.2 \pm 4.67 \dagger$ \\
\hline Baseline SBP (mmHg) & $119.5 \pm 15$ & $114.2 \pm 9.08$ \\
\hline IP SBP (mmHg) & $171.0 \pm 11.1$ & $161.0 \pm 17.17 \dagger$ \\
\hline $2 \mathrm{~min}$ post $\mathrm{SBP}(\mathrm{mmHg})$ & $143.3 \pm 24.1$ & $160.3 \pm 33.79 \dagger$ \\
\hline $10 \mathrm{~min}$ post $\mathrm{SBP}(\mathrm{mmHg})$ & $132.0 \pm 18.1$ & $130.9 \pm 42.39$ \\
\hline Baseline DBP (mmHg) & $76.4 \pm 10.1$ & $70.2 \pm 12.49 \dagger$ \\
\hline IP DBP (mmHg) & $75.3 \pm 9.6$ & $69.7 \pm 12.08 \dagger$ \\
\hline $2 \mathrm{~min}$ post $\mathrm{DBP}(\mathrm{mmHg})$ & $75.0 \pm 11.3$ & $66.2 \pm 11.78 \dagger$ \\
\hline $10 \mathrm{~min}$ post $\mathrm{DBP}(\mathrm{mmHg})$ & $73.2 \pm 7.8$ & $63.5 \pm 11.25 \dagger$ \\
\hline Peak power $\left(\right.$ Watts $\left.\cdot 5 \mathrm{sec}^{-1}\right)$ & $1,291.6 \pm 702.66$ & $1,070.5 \pm 523.97 \dagger$ \\
\hline Mean power $\left(\right.$ Watts $\left.\cdot \sec ^{-1}\right)$ & $736.4 \pm 85.84$ & $678.25 \pm 85.92 \dagger$ \\
\hline Lowest power (Watts $5 \mathrm{sec}^{-1}$ ) & $517.2 \pm 77.33$ & $481.42 \pm 68.38$ \\
\hline $\begin{array}{l}\text { Anaerobic capacity } \\
\left(\text { Watts } 30 \mathrm{sec}^{-1}\right)\end{array}$ & $22,103.5 \pm 2,581.04$ & $20,358.58 \pm 2,625.89 \dagger$ \\
\hline $\begin{array}{c}\text { Body weight relative peak power } \\
\left(\text { Watts } 5 \mathrm{sec}^{-1} \cdot \mathrm{kg}^{-1}\right)\end{array}$ & $15.38 \pm 6.04$ & $13.99 \pm 5.66$ \\
\hline $\begin{array}{c}\text { Body weight relative mean } \\
\text { power }\left(\text { Watts } \cdot \mathrm{sec}^{-1} \cdot \mathrm{kg}^{-1}\right)\end{array}$ & $8.76 \pm 0.81$ & $8.86 \pm 0.67$ \\
\hline Fatigue index $(\%)$ & $48.91 \pm 9.14$ & $48.94 \pm 8.48$ \\
\hline
\end{tabular}

NTproBNP $=\mathrm{N}^{\prime}$ Terminal pro Brain Natriuretic Peptide; IP = immediate post; $\mathrm{BP}=$ blood pressure; $\uparrow=$ significant differences between groups, $\mathrm{p} \leq 0.05$

Thus, in the present study, NTproBNP (ng/mL); Lactate ( $\mathrm{mmol} / \mathrm{L})$ and blood pressure (BP, mmHg) were measured at rest/baseline, immediate-post, 2 minutes post, and 10 minute post a WAnT, in 18-25 year old, wrestlers and untrained young healthy males.

It is well documented that athletes perform better than untrained; especially in the specific sport they compete in [27-29]. In addition, athletes, as well as other trained populations, present with faster and more efficient recovery from physical activity [30-31]. For the better part, athletes and people that are well experienced in challenging situations, tend to cope and recover from such situations better than others [32].

The wrestlers produced significantly higher PP $(1,291.6 \pm 702.66 \mathrm{vs}$. $1,070.5 \pm 523.97), \mathrm{MP}(736.4 \pm 85.84$ vs. $678.25 \pm 85.92)$, insignificantly higher LP $(517.2 \pm 77.33$ vs. $481.42 \pm 68.38)$, and AC $(22,103.5 \pm$
2,581.04 vs. $20,358.58 \pm 2,625.89$ ), averaging $7-20 \%$ higher outputs, in comparison to the untrained subjects. These results may be attributed to a higher muscle mass $(\mathrm{kg})$, motivation to prove themselves to their coaches, and their training status [33].

One may rightfully expect the mathematical ratio between power output and body weight to be higher for athletes rather than an untrained person. The comparison between groups in regards to body weight relative peak and mean power (RPP and RMP, accordingly) showed no significant differences $(15.38 \pm 6.04$ vs. $13.99 \pm 5.66$ and $8.76 \pm 0.81$ vs. $8.86 \pm 0.67$, accordingly). These findings contradict prior findings in literature regarding athletes in comparison to untrained [34]. These results may be explained by the significantly lower body weight $(\mathrm{kg})$ of the untrained subjects, presenting with an average body weight that is lower than that of the wrestlers by $\approx 7.5 \mathrm{~kg}$. This average difference in body weight $(\mathrm{kg})$ is equal to $9.77 \%$ of the untrained subjects' body weight $(\mathrm{kg})$ and $8.9 \%$ of the wrestlers' body weight $(\mathrm{kg})$. This may have easily offset the advantage the wrestlers had regarding PP and MP (Watts).

Fatigue index (\%) for both groups was almost the same (48.91 \pm 9.14 vs. $48.94 \pm 8.48)$. Assuming that all participants truly performed at a maximal anaerobic capacity, one would expect the wrestlers' FI (\%) to greater due to significantly higher mechanical outputs (Watts). This is well documented in the professional literature [34]. Wrestlers, naturally relay on technique rather than peak power, thus, are trained to conserve energy as much as possible during a match, and use little to none outbursts of all-out power [35]. Thus, it is possible, yet was not investigated, that the wrestlers, conserved energy during the test, as part of a strategy imprinted in them. It is also possible, that the wrestlers, wished to avoid fatigue and possible injury, since the study was conducted while they were still competing.

The over-all dynamics of NTproBNP $(\mathrm{ng} / \mathrm{mL})$ was found to be similar to that reported in other studies utilizing aerobic exercises [36], yet with slightly different absolute values. NTproBNP $(\mathrm{ng} / \mathrm{mL})$ levels were higher than previously reported resting values $(35.5 \pm 7.6$ vs. 35.2 \pm 4.83 ) [36]. The researchers attribute these higher levels to creeping nervousness, and probably performance anxiety [37]. Though the fear of needles/blood may contribute to the elevation of NTproBNP (ng/ $\mathrm{mL}$ ) due to nervousness, no data exists to support this argument. The fact that baseline levels were relatively high may have caused the rise from baseline to immediate-post to become insignificant.

The bio-marker's concentration $(\mathrm{ng} / \mathrm{mL})$ in wrestlers and untrained rose from baseline to immediate post $(40.3 \pm 14.1$ vs. $37.3 \pm 9.94$, accordingly), decreased from immediate post to 2 minutes post ( 30.8 \pm 6.0 vs. $33.5 \pm 5.81$, accordingly), and then rose at 10 minutes post ( $32.0 \pm 5.6 v s .45 .1 \pm 11.75$, accordingly). While the differences in both groups were significant between the immediate post and 2 minutes post values, the differences between 2 minutes post and 10 minutes post were significant only in the untrained group. $\triangle$ NTproBNP (ng/ $\mathrm{mL}$ ) between the 2 minutes post and 10 minutes post was significantly higher in for the untrained and insignificantly higher for the wrestlers ( $11.54 \pm 4.3 v s .1 .25 \pm 1.06$, accordingly). These results may be attributed to the athletes' better recovery ability, whereas the untrained subjects needed more time to recover [30-31].

Lactate differences $(\mathrm{mmol} / \mathrm{L})$ were insignificant between groups at rest $(1.9 \pm 1.2$ vs. $2.2 \pm 0.93)$, and significantly different in comparison between all other measurements [38] $(12.5 \pm 2.5$ vs. $7.3 \pm 1.98$, immediate post; $12.4 \pm 3.2$ vs. $11.6 \pm 2.48,2$ minutes post; $11.0 \pm 3.9$ vs. $12.2 \pm 4.67,10$ minutes post; wrestlers $v s$. untrained accordingly) 
A noticeable difference between groups occurred during the transition from immediate-post to 2 minutes post, whereas the untrained subjects continued to elevate their lactate $(\mathrm{mmol} / \mathrm{L})$ levels in average, while the wrestlers showed an insignificant and slight decrease. 10 minutes post, the wrestlers' lactate $(\mathrm{mmol} / \mathrm{L})$ levels were significantly lower than those of the untrained. These data support the notion that athletes recover better and faster than untrained individuals $[30.31,38]$.

The results regarding SBP $(\mathrm{mmHg})$ show that while baseline $(119.5 \pm 15$ vs. $114.2 \pm 9.08)$ and 10 minutes post $(132.0 \pm 18.1$ vs. $130.9 \pm 42.39)$ values were insignificantly higher for the wrestlers, the immediate-post values were significantly higher for wrestlers $(171.0 \pm$ 11.1 vs. $161.0 \pm 17.17$ ), and the 2 minutes post values were significantly higher for the untrained in comparison to the wrestlers $(160.3 \pm 33.79$ vs. $143.3 \pm 24.1)$. These results align perfectly with two facts 1 ) SBP $(\mathrm{mmHg})$ is expected to be greater due to greater mechanical outputs by the wrestlers 2) having better recovery abilities, the wrestlers should present with lower values 2 minutes into recovery [39]. Both groups have not reached their baseline values 10 minutes into recovery, yet had slight and insignificant difference between them.

DPB (mmHg) was found to be significantly higher for all measurements in wrestlers compared to the untrained [39] (76.4 \pm 10.1 vs. $70.2 \pm 12.49$, baseline; $75.3 \pm 9.6$ vs. $69.7 \pm 12.08$, immediate post; $75.0 \pm 11.3$ vs. $66.2 \pm 11.78,2$ minutes post; $73.2 \pm 7.8$ vs. $63.5 \pm 11.25$, 10 minutes post; wrestlers $v s$. untrained accordingly). Both groups had insignificant differences within the group's measurement according to time, and have decreased their DPB ( $\mathrm{mmHg}$ ) from baseline to 10 minutes post.

\section{Conclusions}

Data suggest that the Wingate Anaerobic Test does not put at risk healthy young untrained and trained (wrestlers) males. The data also suggests that the dynamics of the responses of NTproBNP (ng/ $\mathrm{mL}$ ) during the WAnT are somewhat similar to those reported due to aerobic exercise within healthy ranges and populations.

Peak power (Watts) was a strong and positive predictor of immediate-post NTproBNP (ng/mL) levels in wrestlers and untrained alike.

\section{Limitations and future study}

This study is not innocent of mistakes, has its limitations and could be expended and improve in future versions of itself. These limitations include the fact the sleep, caffeine consumption, and exercise were only partially controlled as the subjects self-reported regarding these variables.

In addition, the effect of blood draw on nervousness and NTproBNP levels was not part of the design, and was not controlled for, in spite of the fact that subjects were allowed to look the other way, choose the side from which blood was drawn and have to the most part, have experienced blood draw at least once in their life. The use of a butterfly needle will be preferred in the future.

While the researchers wished to keep the groups equal in sample size, the small number of wrestlers at the University of Mary, limited the study. Future investigation of the topic and perhaps collaboration with other wrestling teams may help improve and enlarge data.

\section{References}

1. Todd A, Astorino, Curtis Bovee, Ashley DeBoe (2015) Estimating Hemodynamic Responses to the Wingate Test Using Thoracic Impedance. J Sports Sci Med 14: 834-840.
2. Fontana P, Betschon K, Boutellier U, Toigo M (2011) Cardiac output but not stroke volume is similar in a Wingate and VO2peak test in young men. Eur J Appl Physiol 111: 155-158. [Crossref]

3. Astorino TA, Cottrell T (2011) Reliability and validity of the Velotron RacerMate cycle ergometer to measure anaerobic power. International Journal of Sports Medicine 32: 1-6.

4. Sagiv M, Amir O, Ben-Sira D, Amir R (2007) Oxygen Delivery of Men and Women at Peak Wingate Test. Brazilian Journal of Biomotricity 3: 65-75.

5. Sagiv M, Ben-Sira D, Goldhammer E, Soudry M (2000) Left ventricular contractility and function at peak aerobic and anaerobic exercises. Medicine and Science in Sports and Exercise 32: 1197-1201.

6. Sudoh T, Kangawa K, Minamino N, Matsuo H (1988) A new natriuretic peptide in porcine brain. Nature 332: 78-81. [Crossref]

7. Stein BC, Levin RI (1998) Natriuretic peptides: physiology, therapeutic potential, and risk stratification in ischemic heart disease. Am Heart $J$ 135: 914-923.

8. Boomsma F, van den Meiracker AH (2001) Plasma A- and B-type natriuretic peptides: physiology, methodology and clinical use. Cardiovasc Res 51: 442-449. [Crossref]

9. Gardner JK, McConnell TR, Klinger TA, Herman CP, Hauck CA, et al. (2003) Quality of life and self-efficacy: gender and diagnoses considerations for management during cardiac rehabilitation. J Cardiopulm Rehabil 23: 299-306.

10. Schnabel R, Lubos E, Rupprecht HJ, Espinola-Klein C, Bickel C, et al. (2006) B-type natriuretic peptide and the risk of cardiovascular events and death in patients with stable angina: results from the AtheroGene study. J Am Coll Cardiol 47: 552-558.

11. Burke MA, Cotts WG (2007) Interpretation of B-type natriuretic peptide in cardiac disease and other comorbid conditions. Heart Fail Rev 12: 23-36.

12. Clerico A, Fontana M, Zyw L, Passino C, Emdin M (2007) Comparison of the diagnostic accuracy of brain natriuretic peptide (BNP) and the N-terminal part of the propeptide of BNP immunoassays in chronic and acute heart failure: a systematic review. Clin Chem 53: 813-822. [Crossref]

13. Ueda S, Minamino N, Sudoh T, Kangawa K, Matsuo H (1988) Regional distribution of immunoreactive brain natriuretic peptide in porcine brain and spinal cord. Biochem Biophys Res Commun 155: 733-739.

14. Antoni FA, Hunter EF, Lowry PJ, Noble JM, Seckl JR (1992) Atriopeptin: an endogenous corticotropin-release inhibiting hormone. Endocrinology130: 1753-1755.

15. Franci CR, Anselmo-Franci JA, McCann SM (1992) The role of endogenous atria natriuretic peptide in resting and stress-induced release of corticotropin, prolactin, growth hormone, and thyroid-stimulating hormone. Proc Natl Acad Sci U S A 89 11391-11395.

16. Imura H, Nakao K, Itoh H (1992) The natriuretic peptide system in the brain implications in the central control of cardiovascular and neuroendocrine functions. Front Neuroendocrinol 13: 217-249.

17. Friedl W, Mair J, Thomas S, Pichler M, Puschendorf B (1999) Relationship between natriuretic peptides and hemodynamics in patients with heart failure at rest and after ergometric exercise. Clin Chim Acta 281: 121-126.

18. Ohba H, Takada H, Musha H, Nagashima J, Mori N, et al. (2001) Effects of prolonged strenuous exercise on plasma levels of atrial natriuretic peptide and brain natriuretic peptide in healthy men. Am Heart $J$ 141: 751-758.

19. Siegel AJ, Lewandrowski EL, Chun KY, Sholar MB, Fischman AJ, et al. (2001) Changes in cardiac markers including B-natriuretic peptide in runners after the Boston marathon. Am J Cardiol 88: 920-923.

20. Herrmann M, Scharhag J, Miclea M, Urhausen A, Herrmann W, et al. (2003) Post-race kinetics of cardiac troponin $\mathrm{T}$ and $\mathrm{I}$ and $\mathrm{N}$-terminal pro-brain natriuretic peptide in marathon runners. Clin Chem 49: 831-834. [Crossref]

21. Niessner A, Ziegler S, Slany J, Billensteiner E, Woloszczuk W, et al. (2003) Increases in plasma levels of atrial and brain natriuretic peptides after running a marathon: are their effects partly counterbalanced by adrenocortical steroids? Eur J Endocrinol 149 : 555-559.

22. Leers MP, Schepers R, Baumgarten R (2006) Effects of a long-distance run on cardiac markers in healthy athletes. Clin Chem Lab Med 44: 999-1003. [Crossref]

23. Banfi G, D’Eril GM, Barassi A, Lippi G (2008) N-terminal proB-type natriuretic peptide (NT-proBNP) concentrations in elite rugby players at rest and after active and passive recovery following strenuous training sessions. Clin Chem Lab Med 46: 247-249.

24. de Bold AJ, Bruneau BG, Kuroski de Bold ML (1996) Mechanical and neuroendocrine regulation of the endocrine heart. Cardiovasc Res 31: 7-18. [Crossref] 
25. Mc Grath MF, de Bold AJ (2005) Determinants of natriuretic peptide gene expression. Peptides 26: 933-943. [Crossref]

26. Ahmad T, Fiuzat M, Mark DB, Neely B, Neely M, et al. (2014) The effects of exercise on cardiovascular biomarkers in patients with chronic heart failure. Am Heart $J 167$ : 193-202.

27. Demirkan E, Kutlu M, Koz M, Özal M, Favre M (2014) Physical Fitness Differences between Freestyle and Greco-Roman Junior Wrestlers. J Hum Kinet 41: 245-251.

28. Isik Ozkan, Cicioglu H, Ibrahim (2016) Dehydration, skeletal muscle damage and inflammation before the competitions among the elite wrestlers. J Phys Ther Sci 28 : $162-168$

29. Karnin $\ddot{A} \square \mathrm{iÄ} \ddagger$ H, KrstuloviÄ $\ddagger$ S, Baï̈ $\ddagger$ M (2013) The influence of body weight on chosen physiological parameters in wrestling. J Hum Kinet 37: 119-127. [Crossref]

30. Wiewelhove T, Raeder C, Meyer T, Kellmann M, Pfeiffer M, et al. (2015) Markers for Routine Assessment of Fatigue and Recovery in Male and Female Team Sport Athletes during High-Intensity Interval Training. PLoS One 10: 0139801.

31. Barak OF, Ovcin ZB, Jakovljevic DG, Crvenkovic ZL, Brodie DA, et al. (2011) Heart Rate Recovery after Submaximal Exercise in Four Different Recovery Protocols in Male Athletes and Non-Athletes. J Sports Sci Med 10: 369-375.

32. Stults-Kolehmainen MA, Sinha R (2014) The effects of stress on physical activity and exercise. Sports Med 44: 81-121. [Crossref]
33. Katarzyna L, Sterkowicz-Przybycien, Sterkowicz S, Zarów RT (2011) Somatotype, Body Composition and Proportionality in Polish Top Greco-Roman Wrestlers. J Hum Kinet 28: 141-154.

34. Driss T, Vandewalle H (2013) The measurement of maximal (anaerobic) power output on a cycle ergometer: a critical review. Biomed Res Int 2013: 589361. [Crossref]

35. Ramirez-Velez R, Argothyd R, Echavez JFM, Puccini MBS, Alban CAL, et al. (2014) Anthropometric Characteristics and Physical Performance of Colombian Elite Male Wrestlers. Asian J Sports Med 5: e23810.

36. Scharhag J, Urhausen A, Herrmann M, Schneider G, B Kramann, et al. (2004) No difference in N-terminal pro-brain natriuretic peptide (NT-proBNP) concentrations between endurance athletes with athlete's heart and healthy untrained controls. Heart 90: $1055-1056$

37. Amir O, Sagiv M, Eynon N, Yamin C, Rogowski O, et al. (2010) The response of circulating brain natriuretic peptide to academic stress in college students. Stress 13: 83-90.

38. Sagiv M, Amir O, Ben-Sira D, Amir R (2001) Oxygen Delivery of Men and Women at Peak Wingate Test. Brazilian Journal of Biomotricity 3: 65-75.

39. Biswas DG, Kher JR (2001) Anaerobic power and cardiorespiratory evaluation in untrained males (18-19 years). Indian J Physiol Pharmacol 45: 122-124.

Copyright: (2017 Saghiv M. This is an open-access article distributed under the terms of the Creative Commons Attribution License, which permits unrestricted use, distribution, and reproduction in any medium, provided the original author and source are credited. 